\title{
NEW RECORDS OF BUXBAUMIA VIRIDIS (BUXBAUMIACEAE, BRYOPHYTA) IN THE SUDETES
}

\author{
Karol Torzewski, Aleksandra Kazienko, Adam Rajsz
}

\begin{abstract}
K. Torzewski, A. Kazienko, A. Rajsz, Department of Ecology, Biogeochemistry and Environmental Protection, University of Wroclaw, Kanonia 6/8, 50-328 Wrocław, Poland, e-mail: karol.torzewski@uwr.edu.pl, aleksandra.kazienko@uwr.edu.pl, adam.rajsz@uwr.edu.pl
\end{abstract}

(Received: October 9, 2017. Accepted: November 3, 2017)

\begin{abstract}
Buxbaumia viridis is a rare, epixylous moss species with boreal range of occurrence. It prefers native, coniferous, spruce-fir forests. Historically the species was recorded several in the Sudetes, but now only two locations are known in this mountain range. In 2017 five unknown B. viridis populations were found in Góry Sowie Landscape Park in the vicinity of Bielawa, in the Bardzkie Mountains near Bardo Śląskie, and in the Sudety Wałbrzyskie Landscape Park on the eastern slope of Waligóra.
\end{abstract}

KeY WORDS: Buxbaumia viridis, Sudety Wałbrzyskie Landscape Park, Góry Sowie Landscape Park, Bardzkie Mts., Sudety Mts.

\section{INTRODUCTION}

The green shield moss Buxbaumia viridis is a especially noteworthy species, because of its unusual rarity and distant in time reports about its occurrence. The species has wide range of occurrence, however, it is strongly dispersed and rarely encountered in Poland and Europe. Due to these fact it was placed in Red data book of European bryophytes (SCHUMACKER \& MARTINY 1995) as endangered (category V), and was placed in annex I of the Berne Convention (KonwenCJA... 1979), and in annex II of the Habitat Directive 92/43/EEC (DyrekTYWA... 1992). Buxbaumia viridis is protected by law in Poland (RozPoRZĄDZENIE... 2014). The species is also considered as "endangered" (category E) in the Polish part of the Carpathians and in Poland (ŻarNowieC et al. 2004).

Buxbaumia viridis is a terophyte which grows on logs of dead trees mainly on fir, spruce and beech, rarely on rich in humic substances soils (STEBEL 2004). The moss is most often noted in native forests (Vončina \& ChachuŁa 2012). In Carpathian Mountains it is primarily associated with beech forests Dentario glandulosae-Fagetum abietetosum. In Pieniny mountains it is recorded in warm fir forests Carici albae-Fagetum abietetosum and beech forests Carici albae-Fagetum typicum. In the north of Poland it was reported on Luzulo pilosae-Fagetum and Stellario-Carpinetum (Stebel 2004, Vončina 2012). In the Sudeten B. viridis was observed on Luzulo nemorosae-Fagetum (СүкоwsKa \& VončIna 2011). Because the protonema grows only on dead wood, $B$. viridis shows close link with forest plant communities. Young individuals rise at the turn of October and November, and in early spring. It is a dioecious plant, which spores ripen in spring (Vončina 2012). The sporophytes are found individually or in small clusters, while minute gametophytes are hard to observe. Sporophyte grows up to $12 \mathrm{~mm}$ high. Seta reach approximately $7 \mathrm{~mm}$ length and has brown colour with noticeable papilla. The oval shape sporangium is green-yellow colour which become brown in later developmental stages. The peristome is composed of four triangular teeth layers (STEBel 2004).

The main distribution center of this species in Poland is the south-eastern part of the country, where it has been described on many sites from different Carpathians parts (Philippe \& Ochyra 2004, CyкоWSKa 2008, VonČIna 2008, ChachuŁa \& VončIna 2010, CYKowsKa \& VonČInA 2011, VonČIna et al. 2011, KoziK \& Vončina 2012, Vončina \& ChachuŁa 2012, ZARZECKI 2012, FudAli et al. 2015, KuCHARZYK \& ToPOLSKA 2015). The moss was also observed both in the northern part of the country (НАјек 2008, 2010, 
2012, SzCZEPANIUK \& KuCHARZYK 2016) and in the Sudetes (SMoczyk \& Wierzcholska 2008, СүкоWsKa \& VonČINA 2011), where in XIX century was described as quite frequently occurring species (SzMAJDA et al. 1991, СүкоwsKa \& Vončina 2011). According to historical data, B. viridis was found on 20 sites in the Sudeten areas located in the Lower Silesian Voivodeship: Kaczawskie Mountains (Limpricht 1890-1904), Miłek Mountain (WiLCZYŃsKA 1974), Wałbrzyskie Mountains - Chełmiec and Mieroszów (MiLde 1869), Sowie Mountains - Walim (Limpricht 1890-1904), Kudowa Zdrój, Zieleniec Valley, Duszniki Zdrój, Śnieżnik, Ślęża massif, Jelenia Góra, Rościsławice, Górzec (MiLDE 1869), Lądek Zdrój (KeRn 1914), Góry Bialskie (Berdowski 1979) and Opolskie Vovoideship: Brynica and Murów (Schoebel 1878 unpbl.), Dębowiec, Głuchołazy (Torka 1931), Przysiecz Reserve (BERDOWSKI 1979). Currently it is reported on one new localization in the Kłodzko region (SMOczyK \& WIERZCHOLSKA 2008) and confirmed on the one described earlier (СүкоWSKA \& Voncina 2011).

New localites of $B$. viridis were found in the Sudetes in 2017. In the Sowie Mountains Landscape Park near Bielawa, Bardzkie Mountains near Bardo and in Sudety Wałbrzyskie Landscape Park on the eastern slope of the Waligóra.

\section{MTERIALS AND METHODS}

Research were conducted in spring 2017 in Kamienne Mountains, Sowie Mountains and Bardzkie Mountains which is part of the Middle Sudetes macro-region (KONDRACKI 2001). Locality was defined as moss cluster located in one stream at a distance not less than 200 meters from each other. The current localities of the species in the Middle Sudetes was expressed in ATMOS grid square system (OchYRA \& SzMAJDA 1981), additionally GPS coordinates were recorded (Garmin 62sc). Nomenclature was adapted after Ochyra et al. (2003) and SzWeykowski (2006). The phytosociological classification was based on that developed by MatuszKiewicz (2005).

\section{RESULTS}

Buxbaumia viridis was found in five new localities in three separate mountain complexes. Positions were noted in commercially managed forests of Luzulo luzuloidis-Fagetum character dominated by Fagus sylvatica and Picea abies additionally Acer pseudoplatanus and in a lesser extent Abies alba.

ATMOS Eb-94: WS Poland, Middle Sudetes, Kamienne Mountains, Sudety Wałbrzyskie Landscape Park $730 \mathrm{~m}$ a.s.l., $50.684^{\circ} \mathrm{N}, 16.298^{\circ} \mathrm{E}$. Sixteen sporogones were observed on 90 centimeter $P$. abies log without bark, in a Luzulo luzuloidis-Fagetum community. Accompanying species: Dicranum scoparium, Herzogiella seligeri, Plagiochila porelloides, Rhizomnium punctatum and Sanionia uncinata. Det. K. Torzewski, 5.04.2017.

ATMOS Eb-96: WS Poland, Middle Sudetes, Sowie Mountains, Góry Sowie Landscape Park. Position I: $760 \mathrm{~m}$ a.s.l., $50.646^{\circ} \mathrm{N}, 16.550^{\circ} \mathrm{E}$. One sporogone was found on $100 \mathrm{~cm}$ P. abies log without bark, in a Luzulo luzuloidis-Fagetum community. Accompanying species: Blepharostoma trichophyllum, Cephalozia bicuspidata, Herzogiella seligeri, Lophocolea heterophylla, Orthodicranum montanum, Rhizomnium punctatum, Sanionia uncinata. Det. K. Torzewski, 20.04.2017. Position II $780 \mathrm{~m}$ a.s.l., $50.637^{\circ} \mathrm{N}, 16.557^{\circ} \mathrm{E}$. Nineteen sporogones were observed on $140 \mathrm{~cm}$ P. abies log without bark, in a Luzulo luzuloidis-Fagetum community. Accompanying species: Cephalozia bicuspidata, Marchantia polymorpha, Herzogiella seligeri, Orthodicranum montanum, Plagiochila porelloides, Rhizomnium punctatum, Tetraphis pellucida. Det. K. Torzewski, 20.04.2017.

ATMOS Fb-16: WS Poland, Middle Sudetes, Bardzkie Mountains. Position I: 490 m. a.s.l., $50.527^{\circ} \mathrm{N}$, $16.686^{\circ} \mathrm{E}$. Two sporogones were observed on $140 \mathrm{~cm}$ P. abies log without bark, in a Luzulo luzuloidis-Fagetum community. Accompanying species: Herzogiella seligeri, Orthodicranum montanum, Tetraphis pellucida. Det. K. Torzewski, 22.04.2017. Position II: 450 m. a.s.l., $50.525^{\circ} \mathrm{N}, 16.686^{\circ} \mathrm{E}$. Five sporogones were observed on $320 \mathrm{~cm}$ Abies alba log without bark, in a Luzulo luzuloidis-Fagetum community. Accompanying species: Dicranum scoparium, Herzogiella seligeri, Orthodicranum montanum. Det. K. Torzewski, 22.04.2017.

\section{DISCUSSION}

Presented data shows five new localities of rare moss Buxbaumia viridis in Polish part of the Middle Sudetes. It allow us to characterize the typical places of occurrence of this species. Buxbaumia viridis is a characteristic native forests species (CIEŚLIŃSKI et al. 1996, Stebel \& Żarnowiec 2014), which is confirmed by: 1. its occurrence in places with low human activity (Sudety Wałbrzyskie Landscape Park, Góry Sowie Landscape Park), 2. appropriate kind of wood as fir and spruce, 3. stage of its decay which is necessary for proper habitat conditions (Vončina \& ChachuŁa 2012). There is no doubt that the occurrence of $B$. viridis is limited by the removing of wood from forests, which could reduce a suitable habitat conditions for the moss (Vončina \& Chachuta 2012). Decrease of the species abundance in the Sudetes over the years can be caused by increased insolation and decreased humidity of habitats as a result of timber harvesting. Current localities of the species should be taken under strict protection for ensure proper living conditions of $B$. viridis. Taking into account historical data of the $B$. viridis occurrence in the Sudetes and the rest of the country, we can assume that Sudetes are one of the main centers of the species in Poland. 


\section{REFERENCES}

BERDOWsKi W. (1979): Nowe stanowiska rzadszych gatunków mchów na Dolnym Śląsku i Opolszczyźnie. Acta Universitatis Wratislaviensis 304, Prace Botaniczne 22: 3-18.

Chachuta P., Vončina G. (2010): The discovery of Buxbaumia viridis (Bryophyta, Buxbaumiaceae) in the Bieszczady National Park. Roczniki Bieszczadzkie 18: 419-423.

Cieśliński S., Czyżewska K., Faliński J.B., Klama H., MutenKo W., ŻarnowieC J. (1996): Relikty lasu puszczańskiego. Zjawiska reliktowe. Wyniki badań w Projekcie CRYPTO na stałej powierzchni BSG: V-100; BPN; oddz. 256. Phytocoenosis 8 (N.S.), Seminarium Geobotanicum 4: 47-64.

Сүкошsка B. (2008): New records of Buxbaumia viridis (Bryophyta, Buxbaumiaceae) in the Polish Carpathians. In: A. Stebel, R. Ochyra (eds). Bryophytes of the Polish Carpathians. Sorus, Poznań: 251-256.

СүкошsкA B., Vončina G. (2011): Recent occurrence of moss Buxbaumia viridis (Bryophyta, Buxbaumiace$a e$ ) in the Kłodzko region (Central and Eastern Sudetes, SW Poland). Casopis Slezskěho zemskěho muzea, Opava (A) 60: 85-89.

DyrekTYWA Rady 92/43/EWG z dnia 21 maja 1992 r. W sprawie ochrony siedlisk przyrodniczych oraz dzikiej fauny i flory. (1992). Dz.U. L 206, 22/07/1992 P. 0007-0050, zmieniona Dyrektywa 97/62/EWG z dnia 27 października $1997 \mathrm{r}$.

Fudali E., Zubel R., Stebel A., RusińsKa A., Górski P., Vončina G., Rosadziński S., CYKowsKa-MarzencKa B., Staniaszek-KIK M., Wierzcholska S., Wolski G., Wojterska M., Wilhelm M., Paciorek T., PiwowarSKI B. (2015): Contribution to the bryoflora of the Roztocze National Park (SE Poland) - Bryophyes of the Świerszcz river valley. Steciana 19(1): $39-54$.

HАјеK B. (2008): Charakterystyka współczesnych stanowisk mchu Buxbaumia viridis na Wysoczyźnie Elbląskiej (Polska północna). Parki Narodowe i Rezerwaty Przyrody 27(4): 27-34.

HАјек B. (2010): Rozmieszczenie, wymagania środowiskowe oraz fenologia rzadkiego mchu Buxbaumia viridis (Moug. ex Lam. \& DC) Brid. ex Moug. \& Nest. (Bryophyta, Buxbaumiaceae) w Trójmiejskim Parku Krajobrazowym. Acta Botanica Cassubica 7-9: 161-175.

HАJEK B. (2012): Nowe stanowisko rzadkiego mchu Buxbaumia viridis (Moug. ex Lam. \& DC) Brid. ex Moug. \& Nest. (Bryophyta, Buxbaumiaceae) na Pomorzu Gdańskim. Acta Botanica Cassubica 11: 207-211.

KeRn F. (1914): Verzeichnis der Moosarten die seit dem Erscheinen der Limprichtschen Werke in Schlesien entdeckt worden sind. Jahresbericht der schlesischen Gesselschaft für vaterländische Cultur 91: 65-72.
Kondracki J. (2001): Geografia regionalna Polski. Wydawnictwo Naukowe PWN, Warszawa.

KonWENCJA o ochronie gatunków dzikiej flory i fauny europejskiej oraz ich siedlisk, sporządzona w Brnie dnia 19 września 1979 r. (1979). http://prawo. sejm.gov.pl/isap.nsf/DocDetails.xsp? id =WDU19960580263 (access: 22.11.2017).

KozIK J., VončIna G. (2012): Odkrycie bezlistu okrywowego Buxbaumia viridis (Bryopsida, Buxbaumiaceae) w Beskidzie Niskim (Karpaty Zachodnie). Roczniki Bieszczadzkie 20: 378-383.

KucharzyK J., TOPOLSKA K. (2015): Inwentaryzacja przyrodnicza bezlistu okrywowego Buxbaumia viridis (Moug. ex Lam. \& DC) Brid. ex Moug. \& Nest. w obszarze Natura 2000 „Eysa Góra” PLH180018 (mscr.). Regionalna Dyrekcja Ochrony Środowiska w Rzeszowie, Warszawa-Myscowa: 1-22.

Limpricht K. (1890-1904): Die Laubmoose Deutschlands, Österreichs und der Schweiz. In: L. Rabenhorst. Kryptogamen-Flora von Deutschland, Österreich und der Schweiz. Bd 2(1-3): 836(1), 853(2), 864(3).

Matuszkiewicz W. (2005): Przewodnik do oznaczania zbiorowisk roślinnych Polski. Wydawnictwo Naukowe PWN, Warszawa.

Milde J. (1869): Bryologia silesiaca, Laubmoos Flora von Nord- und Mittel- Deutschland under besonderer Berücksichtigung Schlesiens und mit Hinzunahme der Floren von Jutland, Holland der Rheinpfalz, von Baden, Franken, Böhmen, Mähren und der Umgegend von München. Verlag von Arthur Felix, Leipzig.

Ochyra R., Szmajda P. (1981): La cartographie bryologique en Pologne. In: J. Szweykowski (ed.). New perspectives in bryotaxonomy and bryogeography. Uniwersytet A. Mickiewicza, Poznań, Seria Biologia 20: 105-110.

Ochyra R., Żarnowiec J., Bednarek-Ochyra H. (2003): Census catalogue of Polish Mosses. Biodiversity of Poland. Vol. 3. Institute of Botany, Polish Academy of Sciences, Kraków.

Phillippe M., Ochyra R. (2004): Occurrence of the moss Buxbaumia viridis (Bryophyta, Buxbaumiaceae) in the Tatra National Park (Poland). In: A. Stebel, R. Ochyra (eds). Bryological studies in the Western Carpathians. Sorus, Poznań: 29-36.

RoZPORZĄDZENIE Ministra Środowiska z dnia 9 października 2014 r. w sprawie ochrony gatunkowej roślin. (2014). Dz.U. 2014, poz. 1409.

Schoebel (1878). Unpublished data, in Herbarium University of Wroclaw. In: Berdowski W. (1979): Nowsze stanowiska rzadszych gatunków mchów na Dolnym Śląsku i Opolszczyźnie. Acta Universitatis Wratislaviensis 304, Prace Botaniczne 22: 3-18.

Schumacker R., Martiny P. (1995): Threatened bryophytes in Europe including Macronesia. In: Red data book of European bryophytes. Part 2: Threat- 
ened bryophytes in Europe including Macronesia. The European Committe for Conservation of Bryophytes, Trondheim: 29-193.

SmoczyK M., WierzcholsKa S. (2008): Wyniki badań botanicznych jako podstawa do rozszerzenia sieci obszarów Natura 2000 w zachodniej części Ziemi Kłodzkiej. In: M. Furmankiewicz, B. Mastalska-Cetera (eds). Problemy wdrażania sieci Natura 2000 na obszarze Sudetów. Muzeum Przyrodnicze w Jeleniej Górze, Jelenia Góra: 101-117.

Stebel A. (2004): Buxbaumia viridis- bezlist okrywowy. In: B. Sudnik-Wójcikowska, H. Werblan-Jakubiec (eds). Poradniki ochrony siedlisk i gatunków Natura 2000 - podręcznik metodyczny. Vol. 9. Gatunki roślin. Ministerstwo Środowiska, Warszawa: 29-32.

Stebel A., Żarnowiec J. (2014): Gatunki puszczańskie we florze mchów Bieszczadzkiego Parku Narodowego (Karpaty Wschodnie). - The primeval forest species in the moss flora of the Bieszczady National Park (Eastern Carpathians). Roczniki Bieszczadzkie 22: 259-277.

SzCZEPANIUK A., KucharZYK J. (2016): New occurrence of rare protected moss species Buxbaumia viridis (Bryopsida, Buxbaumiaceae) in the Białowieża forest. Steciana 20(2): 93-96.

Szmajda P., Bednarek-Ochyra H., Ochyra R. (1991): M. 639. Buxbaumia viridis (DC) Moug. \& Nestl. In: R. Ochyra, P. Szmajda (eds). Atlas of the geographical distribution of spore plants in Poland. Series V. Mosses (Musci). Part 7. W. Szafer Institute of Botany, Polish Academy of Sciences, Adam Mickiewicz University, Kraków-Poznań: 47-52.

SzWEYKOWSKI J. (2006): An annotated checklist of Polish liverworts and hornworts. - Krytyczna lista wątrobowców i glewików Polski. Biodiversity of Poland. Vol. 4. W. Szafer Institute of Botany, Polish Academy of Sciences, Kraków.

ToRKA V. (1931): Die Moosflora von Oberschlesien. Hedwigia 70(3-4): 157-210.
VončINA G. (2008): The occurrance of Buxbaumia viridis (Bryophyta, Buxbaumiaceae) in the Pieniny National Park (Polish Western Carpathians). In: A. Stebel, R. Ochyra (eds). Bryophytes of the Polish Carpathians. Sorus, Poznań: 243-250.

Vončina G. (2012): Bezlist okrywowy Buxbaumia viridis (Moug. ex Lam. \& DC.) Brid. ex Moug. \& Nestl. In: J. Perzanowska (ed.). Monitoring gatunków roślin. Przewodnik metodyczny. Part 2. GIOŚ, Warszawa: 40-52.

Vončina G., ChachuŁa P. (2012): Aktualne występowanie bezlistu okrywowego Buxbaumia viridis (Bryophyta, Buxbaumiaceae) w Pienińskim Parku Narodowym (Polska). Pieniny - Przyroda i Człowiek 12: 81-86.

Vončina G., Cyкоwska B., ChachuŁa P. (2011): Rediscovery of Buxbaumia viridis (Bryophyta, Buxbaumiaceae) in the Tatra and Gorce in Polish Western Carpathians. In: A. Stebel, R. Ochyra (eds). Chorological studies on Polish Carpathian bryophytes. Sorus, Poznań: 171-176.

WILCZYŃSKA W. (1974): Flora mchów i zbiorowisk mszaków Gór Kaczawskich. Monographiae Botanicae 44. Państwowe Wydawnictwo Naukowe, Warszawa.

ZARZECKI R. (2012): Nowe stanowiska Buxbaumia viridis (Buxbaumiaceae, Bryophyta) w południowo-wschodniej Polsce. Fragmenta Floristica et Geobotanica Polonica 19(2): 561-564.

Żarnowiec J., Stebel A., Ochyra R. (2004): Threatened moss species in the Polish Carpathians in the light of a new Red list mosses in Poland. In: A. Stebel, R. Ochyra (eds). Bryological studies in the Western Carpathians. Sorus, Poznań: 9-28.

For citation: Torzewski K., KazienKo A., Rajsz A. (2017): New records of Buxbaumia viridis (Buxbaumiaceae, Bryophyta) in the Sudetes. Steciana 21(3): 93-96. doi: 10.12657/steciana.021.010 